Rev. Int. Contam. Ambie. 32 (4) 407-412, 2016

DOI: 10.20937/RICA.2016.32.04.04

\title{
REMOVAL OF CADMIUM AND LEAD BY ADAPTED STRAINS OF Pseudomonas aeruginosa AND Enterobacter cloacae
}

\author{
Carolina BOJÓRQUEZ ${ }^{1}$, Martín Gabriel FRÍAS ESPERICUETA² and Domenico VOLTOLINA ${ }^{3 *}$
}

${ }^{1}$ Posgrado en Ciencias en Recursos Acuáticos, Universidad Autónoma de Sinaloa. Avenida de los deportes s/n, Ciudad Universitaria, Mazatlán, Sinaloa, México, C.P. 82000

${ }^{2}$ Facultad de Ciencias del Mar, Universidad Autónoma de Sinaloa. Paseo Claussen sin número, Colonia Los Pinos, Mazatlán, Sinaloa, México, C. P. 82000

${ }^{3}$ Laboratorio Universidad Autónoma de Sinaloa, Centro de Investigaciones Biológicas del Noroeste. Paseo Claussen sin número, Colonia Los Pinos, Mazatlán, Sinaloa, México, C. P. 82000

*Autor para correspondencia: voltolin04@cibnor.mx

(Received October 2015; accepted February 2016)

Key words: heavy metals, bacterial strains, adaptation, metal removal

\begin{abstract}
This study determined the cadmium and lead $(\mathrm{Cd}$ and $\mathrm{Pb})$ biosorption of two bacterial strains identified with molecular techniques as Pseudomonas aeruginosa and Enterobacter cloacae. These species were isolated from domestic wastewater and adapted to a maximum of 2.83 and $17.4 \mathrm{mg} / \mathrm{L}$ of $\mathrm{Cd}$ and $\mathrm{Pb}$, respectively. Cd sorption by both strains, determined by atomic absorption spectrophotometry, ranged from 14.4 to $16.5 \%$. However, the difference between strains was not significant. P. aeruginosa and E. cloacae were comparatively more efficient in the sorption of $\mathrm{Pb}(82.47$ and $72.16 \%$ respectively) than for $\mathrm{Cd}$. The amount of $\mathrm{Pb}$ absorbed by the bacterial biomass was significantly higher in P. aeruginosa than in E. cloacae cultures.
\end{abstract}

Palabras clave: metales pesados, cepas bacterianas, adaptación, remoción de metales

\section{RESUMEN}

El presente estudio evaluó la capacidad de absorción y adsorción de cadmio y plomo ( $\mathrm{Cd}$ y $\mathrm{Pb})$ de Psudomonas aeruginosa y Enterobacter cloacae, identificadas mediante técnicas moleculares. Estas dos cepas fueron aisladas de efluentes residuales domésticos y adaptadas hasta concentraciones de $2.83 \mathrm{mg} / \mathrm{L}$ de cadmio y $17.4 \mathrm{mg} / \mathrm{L}$ de plomo. Para determinar la capacidad de remoción de $\mathrm{Cd}$ y $\mathrm{Pb}$ en estas especies, se realizaron cultivos de $24 \mathrm{~h}$ y se cuantificó la cantidad de metal adsorbido y absorbido en la biomasa celular mediante espectrofotometría de absorción atómica. Los resultados muestran que en ambas cepas el porcentaje de adsorción y absorción de Cd se encontró entre el 14.4 y $16.5 \%$ de la concentración inicial, sin diferencias entre cepas. En el caso del Pb ambas cepas son eficientes, ya que los porcentajes retenidos por los dos procesos tanto en $P$. aeruginosa como en E. cloacae suman el 82.47 y $72.16 \%$ de la concentración inicial, respectivamente. La absorción en la biomasa bacteriana resultó significativamente mayor en los cultivos de $P$. aeruginosa. 


\section{INTRODUCTION}

Metals which enter the environment may generate several problems that demand practical solutions. Among these, conventional methods of remediation such as filtration, precipitation or ion exchange, are costly and at times ineffective (Panchanadikar 1994, Cañizares-Villanueva 2000, Vieira and Volesky 2000), while biological systems or biosorbents, including bacteria, fungi or algae are cheaper and frequently more effective, especially when metal concentrations are low (Rodríguez et al. 2006).

Among different groups of microorganisms, bacteria may play an important role in bioremediation because most of them may adapt easily to unfavorable conditions. Some strains of Bacillus, Pseudomonas and Streptomyces have successfully been used as biosorbents (Yilmaz 2003, Gabr et al. 2008, Vijayaraghavan and Yun 2008). Although most of these microorganisms studied for metal bioremediation were isolated in metal-polluted areas, especially industrial wastewaters and mine tailings (Panchanadikar 1994, Samuel et al. 2012). Therefore, their metal resistance might be due to their ability to prevent metal absorption and/or accumulation through some metal-excluding mechanism, or because of genetically determined detoxification processes (Saier 2003, Marrero-Coto et al. 2010). For this reason, they might be less suitable for bioremediation than those able to absorb and accumulate metals in their biomass (Romero et al. 2006, Monge-Amaya et al. 2008).

The Mexican Pacific coast receives contaminants from natural and anthropic sources. Among these, the $\mathrm{Pb}$ and $\mathrm{Cd}$ contents in fish and seafood indicate the extent of their environmental impact, which in some cases may reach the level of concern for human health (Frías-Espericueta et al. 2010). In this study two bacterial species were adapted to high external concentrations of $\mathrm{Cd}$ and $\mathrm{Pb}$, in order to evaluate their ability to remove one or both of these metals by biosorption.

\section{MATERIAL AND METHODS}

\section{Isolation and adaptation to metals}

Samples of urban wastewater were plated onto trypticase soy agar medium (TSA), and incubated at $30{ }^{\circ} \mathrm{C}$ for $24 \mathrm{~h}$ to allow bacterial growth. Colonies with different morphologies were purified with standard procedures (APHA 1992) and maintained on TSA. The pure strains were adapted to $\mathrm{Cd}$ and $\mathrm{Pb}$ with the adaptive pressure selection technique
(Monge-Amaya et al. 2008), using progressively increasing concentrations up to values higher than those reported for mining effluents.

For this, the strains were grown in liquid trypticase soy (TS) medium spiked with concentrations of $\mathrm{Cd}$ increasing from 0.25 to $2.83 \mathrm{mg} / \mathrm{L}$ and from 2.5 to $17.4 \mathrm{mg} / \mathrm{L}$ of $\mathrm{Pb}$. The lowest concentrations selected correspond to the respective chronic concentration criterion (CCC; USEPA 2013). The highest concentrations were higher than those found in mining effluents $(0.309 \mathrm{mg} / \mathrm{L}$ for $\mathrm{Cd}$ and $6 \mathrm{mg} / \mathrm{L}$ for $\mathrm{Pb})$ by Ruíz-López et al. (2010) and Lavado et al. (2010).

Adaptation was evaluated comparing the growth rate and the bacterial concentration determined as optical density (OD), absorbance at $680 \mathrm{~nm}$ of the initial, non-adapted strain, to that of the strain grown in metal-added TS medium. The OD readings were taken after 12 and $24 \mathrm{~h}$, since preliminary experiments with adapted and non-adapted strains showed that in both cases, these periods of time marked the end of exponential growth and the onset of the stationary phase of growth, respectively. Adaptation was assumed when growth rates and OD values of the adapted strains were significantly higher than those determined in the non-adapted strain (Samuel et al. 2013).

\section{Identification of adapted strains}

The strains adapted to $\mathrm{Cd}$ and $\mathrm{Pb}$, were used for total genomic DNA extraction with a Cyclo-Prep ${ }^{\mathrm{TM}}$ Genomic DNA isolation kit (Amaresco ${ }^{\circledR}$ ). The 16S ARNr gene amplification with PCR was performed using $50 \mathrm{ng} / \mu \mathrm{L}$ of the DNA of each strain and the universal primers: Forward 27f.1 (AGR GTT TGA TCM TGG CTC AG) and Reverse 1492R2 (GGT TAC CTT GTT ACG ACT T). The amplification program was: $16 \mathrm{~S}: 94{ }^{\circ} \mathrm{C} / 2{ }^{\prime} \rightarrow 35$ cycles $\left(94^{\circ} \mathrm{C} / 1\right.$, $\left.\rightarrow 56{ }^{\circ} \mathrm{C} / 1^{\prime} \rightarrow 72^{\circ} \mathrm{C} / 1^{\prime}\right) \rightarrow 72{ }^{\circ} \mathrm{C} / 5^{\prime} \rightarrow 4^{\circ} \mathrm{C} / \alpha$. For species identification, the sequences obtained were compared to the public database EzTaxon available online with its analytical functions at http://www. ezbiocloud.net/eztaxon (Kim et al. 2012).

\section{Metal removal and analysis}

The potential of $\mathrm{Cd}$ and $\mathrm{Pb}$ removal by the two adapted strains were determined in two separate experiments. In each experiment both strains were grown in metal-free TS medium for $24 \mathrm{~h}$, centrifuged (3000 rpm, room temperature) and used to start new triplicate cultures in $16 \mathrm{~mL}$ test tubes with $10 \mathrm{~mL}$ of TS medium, added with $2.83 \mathrm{mg} / \mathrm{L}$ of Cd and $17.4 \mathrm{mg} / \mathrm{L}$ of $\mathrm{Pb}$. Triplicate cultures in metal-free medium served as control group, all cultures were maintained in a 
thermoregulated $\left(37^{\circ} \mathrm{C}, 180 \mathrm{rpm}\right.$, continuous operation) Thermo Scientific MaxQ 4000 orbital shaker.

After $24 \mathrm{~h}$ all cultures were centrifuged at 5000 rpm in a refrigerated centrifuge (Sorvall Legend T, $4^{\circ} \mathrm{C}$ ) for $30 \mathrm{~min}$. The supernatant was decanted and stored for metal analysis, the pellet was re-suspended in $10 \mathrm{~mL}$ of $10 \mathrm{mM}$ EDTA, and vortexed for $15 \mathrm{~min}$ to separate the metal adsorbed on the bacterial cell surface (Bashkar and Bhosle 2006). The re-suspended bacteria were centrifuged again at $5000 \mathrm{rpm}$ at $4{ }^{\circ} \mathrm{C}$ for $20 \mathrm{~min}$. The resulting pellet was digested in $3 \mathrm{~mL}$ of concentrated nitric acid (Fluka ${ }^{\circledR}$ ) in a Teflon vessel at $120^{\circ} \mathrm{C}$ for $4 \mathrm{~h}$. No solid residues were left after this digestion.

Samples of the medium of the adsorbed metalcontaining EDTA and of the digested bacterial biomass diluted with $7 \mathrm{~mL}$ of Milli-Q water, were transferred to polypropylene vials, which were stored and refrigerated until analysis (Frías-Espericueta et al. 2009) by atomic absorption spectrophotometry (AAS; Varian SpectrAA-220).

Blanks were used after every 25 samples and the accuracy of the analytical method was evaluated using certified reference materials IAEA-392 (algae) and IAEA-331 (spinach) (IAEA 2009). The recoveries for $\mathrm{Cd}$ were 107.02 and $97.31 \%$, in algae and spinach, respectively. While for $\mathrm{Pb}$ was $90.42 \%$ in algae.

\section{Statistical analysis}

The mean OD values, determined after 12 and $24 \mathrm{~h}$ of growth of the initial and adapted strains of each species, were compared using Student's t-test or the equivalent Mann-Whitney test when data were not normal or homoscedastic (Kolmogorov-Smirnov and Fishers' F test, respectively). The same tests were used to compare the amounts of $\mathrm{Cd}$ and $\mathrm{Pb}$ in the medium, those adhered to the cell walls and that contained in the biomass of each adapted strain. All tests were performed with $\alpha=0.05$.

\section{RESULTS}

The strains were identified as Pseudomonas aeruginosa JCM 5962 (T) and Enterobacter cloacae dissolvens LMG 5962 (T), with similarity percentages of 99.8 and $99.5 \%$, respectively. There were significant differences between the OD readings determined after 12 and $24 \mathrm{~h}$ of growth for the adapted and not adapted strains in TS medium spiked with 2.83 of $\mathrm{Cd}$ or $17.4 \mathrm{mg} / \mathrm{L}$ of $\mathrm{Pb}$. This difference was especially evident with both metals in the case of E. cloacae (Table I).

In the biosorption experiments, both strains retained Cd with equally low efficiency: after $24 \mathrm{~h}$ of exposure the amount adsorbed on cell walls was approximately $7 \%$ of the $\mathrm{Cd}$ added to the growth medium, and the amount in the endocellular fraction was slightly higher, ranging from 7.4 to $9.6 \%$ in E. cloacae and $P$. aeruginosa cultures, respectively. There were no significant differences $(\mathrm{P}>0.05)$ between the total Cd removed by either strain (Table II).

Removal efficiency was far higher in the case of $\mathrm{Pb}$. The mean amount contained in the spent growth medium of the E. cloacae cultures was significantly higher than that determined in the medium of $P$. aeruginosa $(2.13$ and $1.27 \mathrm{mg} / \mathrm{L}$, equivalent to

TABLE I. MEAN ABSORBANCE VALUES ( \pm standard deviation) AT $680 \mathrm{~nm}$ (OPTICAL DENSITIES, OD) OF ADAPTED (A) AND NOT ADAPTED (NA) STRAINS OF Enterobacter cloacae (Ec) AND Pseudomonas aeruginosa (Pa) AFTER 12 AND 24 HOURS WITH $2.83 \mathrm{mg} / \mathrm{L}$ OF Cd OR $17.4 \mathrm{mg} / \mathrm{L} \mathrm{OF} \mathrm{Pb}$

\begin{tabular}{lccccc}
\hline & \multicolumn{2}{c}{$12 \mathrm{~h}$} & \multicolumn{2}{c}{$24 \mathrm{~h}$} \\
\cline { 2 - 4 } \cline { 5 - 5 } & $\mathrm{A}(\mathrm{OD})$ & $\mathrm{NA}(\mathrm{OD})$ & $\mathrm{A}(\mathrm{OD})$ & $\mathrm{NA}(\mathrm{OD})$ \\
\hline $\mathrm{Ec}$ & $1.155 \pm 0.039$ & $0.036 \pm 0.009^{*}$ & $1.517 \pm 0.026$ & $0.379 \pm 0.536^{*}$ \\
$\mathrm{~Pa}$ & $1.282 \pm 0.018$ & $0.348 \pm 0.062^{*}$ & $1.426 \pm 0.035$ & $1.081 \pm 0.045^{*}$ \\
& & \multicolumn{2}{c}{$\mathrm{Pb}$} \\
$\mathrm{Ec}$ & $1.174 \pm 0.006$ & $0.043 \pm 0.008^{*}$ & $1.612 \pm 0.031$ & $0.402 \pm 0.574^{*}$ \\
$\mathrm{~Pa}$ & $1.294 \pm 0.039$ & $0.198 \pm 0.017^{*}$ & $1.653 \pm 0.029$ & $1.112 \pm 0.027^{*}$ \\
\hline
\end{tabular}

* Indicates significant differences between mean values of adapted and non-adapted strains (t-test). 
TABLE II. MEAN CONCENTRATIONS OF Cd (mg/L) IN CULTURE MEDIUM (Me), CELL WALL (M) AND BACTERIAL BIOMASS (BM) OF Enterobacter cloacae (Ec) AND Pseudomonas aeruginosa $(\mathrm{Pa})$ CULTURE IN TS MEDIUM ADDED WITH $2.83 \mathrm{mg} / \mathrm{L}$ OF Cd. THE PERCENTAGES OF THE INITIAL CONCENTRATION ARE IN PARENTHESIS

\begin{tabular}{llcccc}
\hline Strain & & $\mathrm{Me}+$ & $\mathrm{M}$ & $\mathrm{BM}$ & $\Sigma$ \\
\hline $\mathrm{Ec}$ & $\mathrm{mg} / \mathrm{L}$ & $2.344 \pm 0.05$ & $0.210 \pm 0.01$ & $0.210 \pm 0.11$ & $2.760 \pm 0.15$ \\
& $\%$ & $(82.84 \pm 1.82)$ & $(7.30 \pm 0.53)$ & $(7.40 \pm 4.05)$ & $(97.54 \pm 5.26)$ \\
\hline $\mathrm{Pa}$ & $\mathrm{mg} / \mathrm{L}$ & $2.200 \pm 0.27$ & $0.194 \pm 0.03$ & $0.270 \pm 0.16$ & $2.663 \pm 0.143$ \\
& $\%$ & $(77.64 \pm 9.50)$ & $(6.86 \pm 1.03)$ & $(9.62 \pm 5.76)$ & $(94.12 \pm 5.05)$ \\
\hline
\end{tabular}

$+=$ Non parametric (Mann-Whitney) test, $\Sigma=$ Total concentration (sum of $\mathrm{Me}+\mathrm{M}+\mathrm{BM})$

12.5 and $7.3 \%$ of the initial values, respectively). The amount retained by the biomass of $P$. aeruginosa was significantly higher than that of E. cloacae. Cell walls adsorbed approximately similar amounts, close or higher to $15 \%$ of the total $\mathrm{Pb}$ added to the growth medium (Table III).

\section{DISCUSSION}

Most studies on bacteria-mediated remediation of metal-contaminated wastewaters, used bacterial strains isolated from industrial effluents or mining sites. In these cases, bacteria were used after selective pressure, which served to adapt the strains to concentrations of the pollutant higher than those of their original site (Romero et al. 2006, MongeAmaya et al. 2008, Samuel et al. 2012, 2013). This work provides evidence that the same technique can be used for adaptation to high metal concentrations of bacterial strains isolated from wastewater of different origin. Additionally, these adapted strains are good candidates for effluent bioremediation, at least in the case of $\mathrm{Pb}$.
$\mathrm{Pb}$ removal by both strains would have occurred initially by adsorption to the bacterial cell wall, followed by active transmembrane transport, chelation or sequestration of metal ions and accumulation within the cell (King et al. 2007). In the case of Cd, the lack of accumulation in the cell biomass may be explained by metal exclusion, or by detoxification mechanisms similar to those described for antibiotic resistance, which represent the main defense of bacteria in the presence of external toxicants (Saier 2003, Pana 2012).

A similar resistance to several metals, including Cd, was observed in Alcaligenes eutrophus by Nies and Silver (1988). There are numerous additional examples such as the ability to withstand high arsenic concentrations described for several aquatic bacterial strains by Takeuchi et al. (2007). This ability may be due to the activity of members of the cation diffusion facilitators (CDFs) family, which favors the efflux of divalent cations, thus preserving metal homeostasis (Zeytuni et al. 2014), or to one or more of the several, sometimes overlapping, metal resistance systems summarized by Nies (2003) and more recently by Marrero-Coto et al. (2010).

TABLE III. MEAN CONCENTRATIONS OF Pb (mg/L) IN CULTURE MEDIUM (Me), CELL WALL (M) AND BACTERIAL BIOMASS (BM) OF Enterobacter cloacae (Ec) AND Pseudomonas aeruginosa (Pa) CULTURES IN TS MEDIUM ADDED WITH $17.4 \mathrm{mg} / \mathrm{L}$ OF Pb. THE PERCENTAGES OF THE INITIAL CONCENTRATION ARE IN PARENTHESIS

\begin{tabular}{llcccc}
\hline Strain & \multicolumn{1}{c}{$\mathrm{Me}$} & $\mathrm{M}$ & $\mathrm{BM}+$ & $\Sigma$ \\
\hline $\mathrm{Ec}$ & $\mathrm{mg} / \mathrm{L}$ & $2.130 \pm 0.56^{*}$ & $2.663 \pm 0.30$ & $9.890 \pm 0.41^{*}$ & $14.690 \pm 0.77$ \\
& $\%$ & $(12.47 \pm 3.51)$ & $(15.31 \pm 1.71)$ & $(56.85 \pm 2.38)$ & $(84.40 \pm 4.41)$ \\
\hline $\mathrm{Pa}$ & $\mathrm{mg} / \mathrm{L}$ & $1.270 \pm 0.32$ & $2.610 \pm 0.07$ & $11.750 \pm 1.10$ & $15.620 \pm 1.02$ \\
& $\%$ & $(7.30 \pm 1.82)$ & $(14.97 \pm 0.38)$ & $(67.50 \pm 6.33)$ & $(89.77 \pm 5.88)$ \\
\hline
\end{tabular}

$+=$ Non parametric (Mann-Whitney) test, $*=$ significant difference between strains (t-test), $\Sigma=$ Total concentration (sum of Me+M+BM) 


\section{CONCLUSION}

Both strains could be adapted to high external concentrations of $\mathrm{Cd}$ and $\mathrm{Pb}$, which was shown by the poor growth rates of the original (not adapted) strains when cultured in $\mathrm{Cd}$ and $\mathrm{Pb}$-spiked media. However, the differences in $\mathrm{Cd}$ and $\mathrm{Pb}$ retention shown by both strains indicate different resistance mechanisms, which in one case $(\mathrm{Pb})$ allow bacteria to accumulate the metal within their cell biomass. Although, in the second (Cd) bacteria might prevent metal influx, or could maintain internal concentrations of the metal within safe levels through the balance of metal influx and efflux.

For this reason, neither strain is a good candidate for bioremediation of $\mathrm{Cd}$, while both may be used for the treatment of $\mathrm{Pb}$-contaminated wastewater, since $\mathrm{Pb}$ is retained by both strains, in part through adsorption to the cell walls, but mostly through its retention by absorption within the bacterial biomass.

\section{ACKNOWLEDGMENTS}

Supported with Universidad Politécnica de Sinaloa (UPSIN) research funds and through Consejo Nacional de Ciencia y Tecnología (CONACyT) INFRA-2012-01-188029 grant. The first author is the recipient of a CONACyT scholarship. H. Bojórquez helped with metal analysis.

\section{REFERENCES}

APHA (1992). Standard methods for the examination of water and wastewater, $18^{\text {th }}$ ed. American Public Health Association. Washington, USA, 1325 pp.

Cañizares-Villanueva R.O. (2000). Bioadsorción de metales pesados mediante el uso de biomasa microbiana. Rev. Lat. Microbiol. 42, 131-143.

Frías-Espericueta M.G., Osuna-López J.I., Voltolina D., Beltrán-Velarde M., Izaguirre-Fierro G., López-López G., Muy-Rangel M.D. and Rubio-Carrasco W. (2009). The contents of $\mathrm{Cd}, \mathrm{Cu}, \mathrm{Pb}$ and $\mathrm{Zn}$ of the white shrimp Litopenaeus vannamei (Boone, 1931) of six coastal lagoons of Sinaloa, NW Mexico. Rev. Biol. Mar. Oceanogr. 44, 197-201.

DOI: $10.4067 / \mathrm{S} 0718-19572009000100020$

Frías-Espericueta, M.G., Osuna-López J.I., IzaguirreFierro G., Aguilar-Juárez M. and Voltolina D. (2010). Cadmio y plomo en organismos de importancia comercial de la zona costera de Sinaloa, México: 20 años de estudios. Oceánides 25, 27-39.
Gabr R.M., Hassan S.H.A. and Shoreit A.A.M. (2008). Biosorption of lead and nickel by living and nonliving cells of Pseudomonas aeruginosa ASU 6a. Int. Biodeterior. Biodegrad. 62, 195-203.

DOI: 10.1016/j.ibiod.2008.01.008

IAEA (2009). Reference material online catalog. International Atomic Energy Agency, Vienna [online] http:// nucleus.iaea.org/rpst/ReferenceProducts/ReferenceMaterials/ 16/06/2015.

Kim O.S., Cho Y.J., Lee K., Yoon S.H., Kim M., Na H., Park S.C., Jeon Y.S., Lee J.H., Yi H., Won S. and Chun J. (2012). Introducing EzTaxon: a prokaryotic 16S rRNA gene sequence database with phylotypes that represent uncultured species. Int. J. Syst. Evol. Microbiol. 62, 716-721.

DOI: 10.1099/ijs.0.038075-0

King P., Rakesh N., Beenalahari S., Prasanna Kumar Y. and Prasad V.S.R.K. (2007). Removal of lead from aqueous solution using Syzygium cumini L: equilibrium and kinetic studies. J. Hazard. Mater. 142, 340-347. DOI: 10.1016/j.jhazmat.2006.08.027

Lavado C., Sun M. R. and Bendezú S. (2010). Adsorción de plomo en efluentes industriales usando carbones activados con $\mathrm{H}_{3} \mathrm{PO}_{4}$. Rev. Soc. Quím. Perú 76, 165-178.

Marrero-Coto J., Díaz-Valdivia A. and Coto-Pérez O. (2010). Mecanismos moleculares de resistencia a metales pesados en las bacterias y sus aplicaciones en la biorremediación. Rev. CENIC, Cien. Biol. 41, 67-78

Monge-Amaya O., Valenzuela-García J.L, Acedo-Félix E., Certucha-Barragán M.T. and Almendáriz-Tapia F.J. (2008). Biosorción de cobre en sistema por lote y continuo con bacterias aerobias inmovilizadas en zeolita natural (clinoptilolita). Rev. Int. Contam. Ambie. 24, 107-115.

Nies D.H. (2003). Efflux-mediated heavy metal resistance in prokaryotes. FEMS Microbiol. Rev. 27, 313-339. DOI: $10.1016 / \mathrm{S} 0168-6445(03) 00048-2$

Nies D.H. and Silver S. (1988). Plasmid-determined inducible efflux is responsible for resistance to cadmium, zinc and cobalt in Alcaligenes eutrophus. J. Bacteriol. 171, 896-900.

Pana M. (2012). Antibiotic resistant bacteria - a continuous challenge in the new millennium. Intech, Rijeka, Croatia, 586 pp. DOI: $10.5772 / 1058$

Panchanadikar V.V. (1994). Biosorption process for removing lead (II) ions from aqueous effluents using Pseudomonas sp. Int. J. Environ. Stud. 46, 243-250. DOI: 10.1080/00207239408710929

Rodríguez C., Quesada A. and Rodríguez E. (2006). Nickel biosorption by Acinetobacter baumannii and Pseudomonas aeruginosa isolated from industrial wastewater. Brazil. J. Microbiol. 37, 465-467. DOI: $10.1590 / \mathrm{S} 1517-83822006000400012$ 
Romero M.C., Reinoso E.H., Urrutia M.I. and MorenoKiernan A. (2006). Biosorption of heavy metals by Talaromyces helicus: a trained fungus for copper and biphenyl detoxification. J. Biotech. 9, 221-226. DOI: 10.2225/vol9-issue3-fulltext-11

Ruíz-López V., González-Sandoval M.R., BarreraGodínez J.A., Moeller-Chávez G., Ramírez-Camperos E. and Durán-Domínguez de-Bazúa M.C. (2010). Cadmium and zinc removal from a mining reprocessing aqueous stream using artificial wetlands. Tecnol. Cien. Ed. (IMIQ) 25, 27-34.

Saier M.H.J. (2003). Tracing pathways of transport protein evolution. Mol. Microbiol. 48, 1145-1156.

DOI: 10.1046/j.1365-2958.2003.03499.x

Samuel J., Paul M.L., Pulimi M., Nirmalra M.J., Chandrasekaran N. and Mukherjee A. (2012). Hexavalent chromium bioremoval through adaptation and consortia development from Sukinda chromite mine isolates. Ind. Eng. Chem. Res. 51, 3740-3749.

DOI: $10.1021 /$ ie201796s

Samuel J., Lien P.M., Ravishankar H., Mathut A., Priya S.D., Natarajan C. and Mukherjee A. (2013). The differential stress response of adapted chromite mine isolates Bacillus subtilis and Escherichia coli and its impact on bioremediation potential. Biodegradation $24,846-852$.

DOI: $10.1007 / \mathrm{s} 10532-013-9631-8$
Takeuchi M., Kawahata H., Gupta L.P., Kita N., Morishita Y., Ono Y. and Komai T. (2007). Arsenic resistance and removal by marine and non-marine bacteria. $\mathrm{J}$. Biotechnol. 127, 434-442. DOI: $10.1016 /$ j.jbiotec.2006.07.018

USEPA (2013). National recommended water quality criteria. United States Environmental Protection Agency. Washington, U.S.A. [online] http://water.epa.gov/ scitech/swguidance/standards/criteria/current/index. cfm 03/07/2015

Vieira R. and Volesky B. (2000). Biosorption: a solution to pollution?. Int. Microbiol. 3, 17-24.

Vijayaraghavan K. and Yun Y.S. (2008). Bacterial biosorbents and biosorption. Biotechnol. Adv. 26, 266-291. DOI: 10.1016/j.biotechadv.2008.02.002

Yilmaz E.I. 2003. Metal tolerance and biosorption capacity of Bacillus circulans strain EB1. Res. Microbiol. 154, 409-415. DOI: 10.1016/S0923-2508(03)00116-5

Zeytuni N., Uebe R., Maes M., Davidov G., Baram M., Raschdorf O., Nadav-Tsubery M., Kolusheva S., Bitton R., Goobes G., Friedler A., Miller Y., Schüler D. and Zarivach R. (2014). Cation diffusion facilitators transport initiation and regulation is mediated by cation induced conformational changes of the cytoplasmic domain. PLoS ONE 9, e92141.

DOI: 10.1371/journal.pone.0092141 